\title{
We, the Peoples: Populist Leadership, Neoliberalism and Decoloniality
}

\section{Nosotros, los pueblos: liderazgo populista, neoliberalismo y descolonización}

\author{
Lars Cornelissen ${ }^{1}$ \\ Radboud University Nijmegen (Holanda)
}

Recibido: 11-02-19

Aprobado: 14-04-19

\begin{abstract}
This article engages with the limits of Ernesto Laclau's theory of populism, focusing on the logic of popular identification. The central argument is that the Laclauian framework is incapable of accounting for recent forms of populism that articulate a decolonial mode of identification. More specifically, the article shows that for Laclau, leadership and exclusion are necessary components of popular identification, in which the identity of 'the people' depends on the prior symbolic articulation of both an enemy and a leader. Although this theory of populism is well-positioned to explain how populist leadership functioned in several mid-century Latin American varieties of populism, it founders when faced with more recent forms of populist identification. Careful analysis of contemporary Ecuadorian and Bolivian populisms shows that these implicitly reject the Laclauian model of identification, articulating instead a decolonial model that advocates the plurality of identities and mobilises rich national histories of anti-colonial resistance.
\end{abstract}

Key-words: Ernesto Laclau, populism, popular identification, decoloniality, neoliberalism, Perónism.

\footnotetext{
${ }^{1}$ (1.s.cornelissen@brighton.ac.uk). Completed his PhD at the University of Brighton in 2018. His research is primarily on the history of neoliberal thought. He is the author of numerous articles on this subject, which have appeared in Constellations, History of European Ideas, and Political Theology amongst others. Presently he is active as the Academic Editor for the Independent Social Research Foundation.
} 


\section{Resumen}

Este artículo aborda los límites de la teoría del populismo de Ernesto Laclau centrándose en la lógica de la identificación popular. El argumento central es que el marco laclauiano es incapaz de dar cuenta de formas recientes de populismo que articulan un contexto de identificación descolonizador. Más específicamente, el artículo muestra que para Laclau el liderazgo y la exclusión son componentes necesarios de la identificación popular, en la que la identidad de "el pueblo" depende de la articulación simbólica previa de un enemigo y un líder. Aunque esta teoría populista es suficiente para explicar cómo se articula el liderazgo populista en distintas modalidades populistas latinoamericanas de mediados de siglo, zozobra cuando se enfrenta a formas más recientes de identificación populista. Un análisis cuidadoso de los populismos ecuatorianos y bolivianos contemporáneos muestra que éstos rechazan implícitamente el modelo laclauiano de identificación, articulando en cambio un modelo descolonizador que defiende la pluralidad de identidades y moviliza historias nacionales vivas de resistencia anticolonial.

Palabras-clave: Ernesto Laclau, populismo, identificación popular, descolonización, neoliberalismo, peronismo.

\section{Introduction}

Populism is proving to be one of the key problems of early $21^{\text {st }}$-century theory and politics. As across the globe populist movements, left- and rightwing alike, are gaining traction the scholarly community is scrambling to make sense of this phenomenon and to register its implications. Accordingly, theories of populism abound even as received theoretical frameworks are being reconsidered in the face of the populist challenge.

One hugely influential theorist of populist politics was the late Ernesto Laclau (1935-2014), who dedicated the last ten years or so of his life to reconceptualising populism. Setting out to rescue the concept from its negative connotations, the Argentinian philosopher succeeded at forging a generative theory of populism, forwarded most prominently in his 2005 book On Populist Reason. The analytical framework presented there soon became the key theoretical reference point for a variety of self-consciously populist movements, figures, and parties, including SYRIZA in Greece, Podemos in Spain, and JeanLuc Mélenchon in France. It has similarly inspired a plethora of publications, both scholarly and political, on populism. This body of literature encompasses work by his long-standing collaborator and interlocutor, Chantal Mouffe (2005; 2018), studies in populist discourse undertaken by his followers and former 
students (e.g. Katsambekis 2017; Stavrakakis et al. 2017), as well as critiques from a variety of angles (e.g. Gauna 2017; Villacañas Berlanga 2010; Žižek 2006).

The present essay addresses itself to one particular aspect of Laclau's theory of populism: the role it assigns to the figure of the leader, whose name and identity serve, in Laclau's view, as a key component of the process of populist identification. The leader functions, in other words, as the glue that holds a populist movement together, the identity of the movement being invested in his or her name, which in turn becomes the name of the movement. My argument is that, although it is capable of explaining several historical instances of populist identification, the Laclauian framework reaches its limits when confronted with certain contemporary forms of populism, particularly those that, over the past decade or so, have come out of Bolivia and Ecuador. Indeed, rather than investing themselves in the category of leadership, with its necessarily unitarian tendencies, these populisms are grounded in a pluralist understanding of identity, according to which the people is always already plural - made up of peoples, in the plural, that cannot be reduced to one (national) identity. It will be argued that this pluralist conception of popular identification has its roots in a decolonial tradition that sits at odds with the decidedly European pedigree of Laclau's philosophical background.

The essay is structured as follows. In the first section I trace the contours of Laclau's theory of populism, focusing particularly on the role assigned therein to the concept of the leader. In the second I reflect on the populist strategy of Juan Perón, who is often cited as an example of populist leadership as Laclau sees it. I suggest that more than being merely an example of the Laclauian framework, Perónism is its paradigm, forming the historical anchor of Laclau's thinking. In the third, I turn to Bolivian and Ecuadorian populism in order to begin articulating a critique of the Laclauian model. On the basis of an engagement with both nations' constitutions, I suggest that the pluralist understanding of popular identity that underpins them poses a challenge to Laclau's theory. In concluding the essay, I reflect briefly upon the theoretical and political implications of my contention.

\section{Laclau's Conception of Leadership}

In order to explain Laclau's conception of leadership, and where it sits in his theory of populism, I will first have to introduce several key concepts that underpin the Laclauian framework. In doing so, however, I will not be able to do justice to the rich complexity of Laclau's philosophical system². For my

${ }^{2}$ For critical and introductory texts on Laclau's philosophy, see for instance Critchley \& Marchart 
present purposes, however, it suffices to offer a brief summary of the theory of popular identification as presented in On Populist Reason and several related writings.

It should first be noted that for Laclau, the concept of populism does not signify a certain ideological doctrine or a determinate political agenda. It is not a movement with easily identifiable characteristics or even a style of politics, which would see politicians on either fringe of the political spectrum rail against immigration, the European Union or the ruling élites, as the case may be. Rather, populism signifies a logic that underpins all political life, referring to an ontological register rather than an ideological one. Populist politics, differently put, is not defined by its (ideological) content but by its (ontological) form. In Laclau's words: "we could say that a movement is not populist because in its politics or ideology it presents actual contents identifiable as populistic, but because it shows a particular logic of articulation of those contents - whatever those contents are" (Laclau 2005b, 33). What, then, is meant by a populist 'logic of articulation' and what does it entail?

The most elementary building-block of Laclau's theory of populism is the concept of social demands. A social demand, for Laclau, is quite simply an appeal, put forward by any given social group, for a change in policy. Emerging from a failure by the authorities to meet the needs, desires or preferences of the populace, a social demand indexes a certain lack: a lack of provision, of receptivity, of efficiency. Since the social order is never entirely in harmony with itself, social demands are an inevitable feature of social life. After having been issued, a social demand may travel several different paths. It could be resolved by the authorities, for instance, who might allocate more resources to the issue or change its policy as requested. Equally, the campaign might lose momentum, causing the demand to peter out. Should the social demand remain unsatisfied, however, it may come to exist within a larger field of similarly unsatisfied demands, and whilst each of these may revolve around a different matter altogether, they are united in their remaining unresolved. At this point, it is possible (though not inevitable) for a number of such unsatisfied social demands to be articulated together, as the social groups in question realise that there exists what Laclau terms "an equivalential relation" (2005a, 73) between their various demands. What ties them together, in other words, is their opposition to the authorities, potentially resulting in "a widening chasm separating the institutional system from the people" (Laclau 2005a, 74).

At this point, the conditions are in place for a populist collective to emerge, born out of a series of unsatisfied demands and subjectified in opposition to the authorities. Let me quote Laclau at some length:

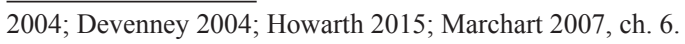

Araucaria. Revista Iberoamericana de Filosofia, Política, Humanidades y Relaciones Internacionales, año $21, \mathrm{n}^{\circ} 42$. Segundo semestre de 2019. Pp. 529-551. ISSN 1575-6823 e-ISSN 2340-2199 doi: 10.12795/araucaria.2019.i42.23 
So we have here the formation of an internal frontier, a dichotomization of the local political spectrum through the emergence of an equivalential chain of unsatisfied demands. The requests are turning into claims. We will call a demand which, satisfied or not, remains isolated a democratic demand. A plurality of demands which, through their equivalential articulation, constitute a broader social subjectivity we will call popular demands - they start, at a very incipient level, to constitute the 'people' as a potential historical actor. Here we have, in embryo, a populist configuration. We already have two clear preconditions of populism: (1) the formation of an internal antagonistic frontier separating the 'people' from power; and (2) an equivalential articulation of demands making the emergence of the 'people' possible. (Laclau 2005a, 74)

It is clear, then, that for Laclau a political movement is populist if it arose out of the articulation of several demands, united not in their positivitybecause they consist of the same content-but in their negativity-because they oppose the same enemy. What, it should now be asked, does this mean for populist identification? How, in other words, do popular demands result in a collective subjectivity that claims to be 'the people'?

For Laclau, processes of identification never take place in a vacuum, detached from the social field within which they arise. Identities, in other words, emerge within the social and, as a result, they gain their substance from the social. However, because, in Laclau's account, there exists no transcendental surplus outside of the social, any one identity exists in its positivity solely insofar as it differs from all other identities that constitute the totality of the social field. Identity, in a word, can only ever be differential. ${ }^{3}$ In the process of popular identification, that is, in the establishment of 'the people', the logic of identification through differentiation passes through two key moments: the moment of antagonism and the moment of leadership. Let me look at each in turn.

Because, in Laclau's view, identification only ever takes place in and as a play of differences, the totality of all the differences that are implied in any one identity itself requires a constitutive outside, without which that totality would remain insubstantial. The totality of all differences is, in other words, itself dependent upon differentiation. However, that which functions as the totality's constitutive outside cannot itself be another mere difference, since that would make it simply another element of the totality. Rather, it must be an "excluded [element], something that the totality expels from itself in order to constitute itself' (Laclau 2005a, 70). This is what Laclau calls 'antagonism': the constitutive limit of all identification that is included only as exclusion (see Laclau 1996, 52).

In the case of popular identification, the role of the excluded element is fulfilled by the 'enemy' of 'the people', the oppositional party in defiance of

\footnotetext{
${ }^{3}$ I have here concisely summarised a very complex and dense string of argumentation. For Laclau on identification, see especially Laclau 1996; 2005a, 69ff; and also Marchart 2007, ch. 6.
} 
which the various popular demands are articulated into a chain of equivalence. In Laclau's words:

This should be evident: for the equivalential chain to create a frontier within the social it is necessary somehow to represent the other side of the frontier. There is no populism without discursive construction of an enemy: the ancien régime, the oligarchy, the Establishment or whatever. (Laclau 2005b, 39)

This 'enemy' does not, of course, exist outside its being constituted by (and in) the process of popular identification: the two sides of the antagonistic frontier are mutually constitutive, functioning as each other's condition of possibility. The antagonistic moment, then, consists of the exclusion of a radical Other, whose otherness and exclusion are necessary for the establishment of the identity of 'the people'.

However, for a collection of social groups united through the logic of equivalence to become a 'people' in the proper sense of the word, identification through exclusion is not enough. The construction of an enemy is, as it were, a necessary but insufficient condition of popular identification. Indeed, if the establishment of an antagonistic frontier may be seen as the negative pole of popular identification, the question remains as to what constitutes its positive pole. Here the figure of the leader comes into play: the leader, on Laclau's account, is the figure whose very name completes the process of identification. Because this point is crucial to my overall argument, I shall unpack it in detail.

As noted above, the logic of equivalence articulates disparate and heterogeneous social demands, which come to form an equivalential chain not because their content is the same, but because, despite their differences, they are united in their opposition to the institutional system that has failed to address them. For Laclau, such a chain can maintain its coherence only when one of its links - that is, one particular social demand - comes to stand in for the whole chain. Although the popular demand thus consists of multiple social demands, it comes to be unified under the banner of only one of them. In order to be able to fulfil this role, the signifier that originally referred to one particular demand only must be 'emptied' of its particular content, such that it may become a placeholder for all the other elements of the equivalential chain. This is what Laclau calls an 'empty signifier' (see especially Laclau 1996, ch. 3; 2005a, ch. 5): a signifier that represents the totality of the popular demands and that, as a result, is at once particular (since it emerged from and as a particular social demand) and universal (since it stands in for the entire equivalential chain).

However, in the case of popular identification in its purest form (which, for Laclau, occurs at moments of total breakdown of the institutional order) the assemblage of heterogeneous demands that makes up the popular struggle is so vast that the role of the empty signifier cannot be fulfilled by one of its 
constitutive demands, since these are, by their very nature, marked too strongly by their original particularity. At this point, the empty signifier that symbolises the equivalential chain as a whole must become a name rather than a demand, as the former can succeed where the latter must fail: it can render itself so empty that it can signify the totality of the popular struggle. Here is Laclau:

[I] - given the radical heterogeneity of the links entering into the equivalential chain - the only source of their coherent articulation is the chain as such, and if the chain exists only in so far as one of its links plays the role of condensing all the others, in that case the unity of the discursive formation is transferred from the conceptual order (logic of difference) to the nominal one. This, obviously, is more the case in situations where there is a breakdown or retreat of the differential/institutional logic. In those cases, the name becomes the ground of the thing. An assemblage of heterogeneous elements kept equivalentially together only by a name is, however, necessarily a singularity. The less a society is kept together by immanent differential mechanisms, the more it depends, for its coherence, on this transcendent, singular moment. But the extreme form of singularity is an individuality. In this way, almost imperceptibly, the equivalential logic leads to singularity, and singularity to identification of the unity of the group with the name of the leader. (Laclau 2005a, 100; see also Laclau 2005b, 40)

Ontologically speaking, then, the concept of the leader is a limit concept, as it were: its function is to resolve the tension inherent in the logic of equivalence, which alone is incapable of producing a signifier 'empty' enough to bind all of the heterogeneous elements that constitute a truly popular movement. When the logic of populism is pushed to its (ontological) limits, in other words, leadership becomes its necessary cornerstone. Here again it should be emphasised that the relationship between the leader and 'the people' is one of co-constitution. Much like the enemy against which 'the people' defines itself, the leader does not pre-exist his or her being constituted as part of the larger process of popular identification. Moreover, the leader does not stand above, let alone outside, 'the people': he or she is an equal, a 'primus inter pares', as Laclau (2005a, 161) would have it, whose qualities make them fit to lead but do not therewith make them superior.

Thus stands the philosophical defence of populist leadership. Although nobody has done more to unpack the ontological dimension of this concept, Laclau's basic contention that, in the final analysis, populist identification must pass through the figure of the leader has been echoed by many of his followers. Indeed, on an analytical register, many of Laclau's followers have come to view populist leadership as a crucial tool in the scholarly endeavour to study and map populist movements (e.g., García Agustín \& Briziarelli 2018; Katsambekis 2017; Stavrakakis et al. 2017). On a strategic register, meanwhile, 
those seeking to invigorate left-wing populism have come to see leadership as a necessary feature of the populist's arsenal. Thus, in a dialogue about the nature and political agenda of Podemos, Chantal Mouffe and Íñigo Errejón discuss the topic of 'charismatic leadership', arguing that despite its problematic connotations, leadership is a crucial feature of populist politics. Errejón opens this discussion by contending that charismatic leadership constitutes "the indispensable intellectual, moral, and affective glue of a new people", to which Mouffe responds that " $[\mathrm{t}] \mathrm{o}$ turn heterogeneous demands into a collective will it's necessary to have a figure that can represent that unity, and I don't think there can be a populist moment without leadership, that's for sure" (Mouffe \& Errejón 2016, 109). In her most recent book, For a Left Populism, Mouffe similarly argues that "the hegemonic operation of constructing a people requires an articulating principle to connect in a chain of equivalence the manifold democratic demands constituting the collective will", adding that "the figure of a leader" is one of the two forms this principle may take $(2018,70)$.

In sum, the Laclauian approach to populism rests on a complex theory of identification, according to which the process through which a 'people' constructs itself necessarily passes through two key moments: on the one hand, there must exist a relationship of antagonism to an enemy, whose exclusion as radically Other makes possible identification through differentiation; on the other hand, 'the people' must rally behind an empty signifier that can symbolise the popular struggle as a whole-which, in its purest form, is the name of a leader.

\section{Leadership and Populism}

Having offered an overview of Laclau's theory of populism, I now wish to situate it against its historical background, which, in this case, means relating it to the populist politics of Juan Perón. It is in Peronism, I shall argue, that the Laclauian framework finds its paradigmatic expression. Accordingly, this framework is well-placed to explain and interpret instances of populism that resemble it, such as Varguism or, more recently, Chavism. My intention, however, is to prepare the ground for a discussion, pursued in the next section, of populisms that do not resemble the Peronist paradigm in the same way.

To begin, it is worth noting that Laclau himself once made it clear that his effort to theorise populism was, in essence, an effort to theorise a certain Latin American experience. Thus Laclau opens a revealing 1977 essay entitled 'Towards a Theory of Populism', published in his Politics and Ideology in Marxist Theory, by noting that "the concepts to be employed have been developed basically with Latin American experience in mind" (Laclau 1977, 
144). Although it would be wrong to assume that the impetus for this early essay - which anticipates some of the claims made in On Populist Reason but is still very rudimentary — can, by implication, be ascribed to all of Laclau's work on populism, this comment nevertheless implies that the problem field that, for him, surrounded the populist experience was conditioned by Peronism. ${ }^{4}$ With this is mind, it is worth briefly relating Laclau's theoretical framework to the populism of Perón, focusing in particular on how Peronism succeeded in constructing a popular identity. ${ }^{5}$

To any casual observer, Peronism is first of all an exemplar of a form of populism that revolves around charismatic leadership. It is unsurprising, then, that in the literature on populism, Peronism is one of the standard examples of the logics of populist leadership (see Canovan 1981; Laclau 2005a; Panizza 2005; Taggart 2000). There is indeed no doubt that, as its very name signifies, Peronism revolves centrally around the figure of Juan Domingo Perón. Yet, the exact nature of Perón's place in the broader formation of Peronism is a very complex - and therefore hotly contested - subject. Because I lack the space to unpack this problem fully, I shall focus solely on what might be considered the birth of Peronism proper: Perón's speech to his followers on the $17^{\text {th }}$ of October 1945.

On 17 October 1945, large numbers of demonstrators gathered in the Plaza de Mayo in the centre of Buenos Aires to demand that the military government release Perón, who had been jailed approximately a week earlier (see also James 1988). Faced with the prospect of riots and strikes, the government complied rapidly, releasing Perón that same evening and urging him to address the crowds with the aim of calming them down. Perón succeeded in doing so, but did not leave it there: indeed, he presented himself to those crowds as their leader, effectively generating Peronism as a real historical force. Crucially, this genesis relied upon a double gesture: for Peronism to be possible, Perón had to construct at once a people out of the masses that had gathered in the Plaza and a leader out of himself. This is clear from the very opening of his speech, where he explains that earlier that day he had resigned as army general so that, released from active service to the State, he could instead dedicate himself to its citizens. Here is Péron: ${ }^{6}$

\footnotetext{
${ }^{4}$ In a tribute to Laclau written after his death in 2014, Paula Biglieri (2015) argues that Laclau's theoretical work developed out of his own political activism, which, as is well known, was aligned to Peronism.

${ }^{5}$ I cannot here provide any background regarding the history of Peronism or Juan Perón and his spouses. For a general introduction to these matters, see for instance Page 1983; Romero 2002; Schamis 2013.

${ }^{6}$ Perón's speech (in Spanish) can be accessed in part on YouTube: https://www.youtube.com/ watch?v=G0EQQildKCE. For the full, unredacted speech (in Spanish), see https://www.educ.ar/ recursos/129178/discurso-de-juan-d-peron-17-de-octubre-de-1945. The translation presented here is my own, with the help of German Primera.
}

Araucaria. Revista Iberoamericana de Filosofia, Política, Humanidades y Relaciones Internacionales, año $21, \mathrm{n}^{\circ} 42$. Segundo semestre de 2019. Pp. 529-551. ISSN 1575-6823 e-ISSN 2340-2199 doi: 10.12795/araucaria.2019.i42.23 
I have voluntarily renounced the highest honour that a soldier can aspire to: to wear the palms and laurels of the general of the nation. I have done so because I want to continue being Colonel Perón and to put myself with this name to the integral service of the authentic Argentine people [del auténtico pueblo argentino].

I leave, then, the honourable and sacred uniform given to me by the country, to wear the coat of the civilian and to blend in [mezclarme] with that suffering and sweaty mass $[\mathrm{masa}]$ that constitutes, through its work [trabajo], the greatness of the country.

Here, already, the reciprocal articulation of Perón-as-leader and the Argentine people is taking shape: it is in dedicating himself to the people that Perón assists that people in forming itself. What is more, he presents himself as one of the people, not their superior - a primus inter pares, as Laclau might say. And although the reference to the people's 'authenticity' may suggest that the people pre-existed Perón's interpellation of them, his reference, in the next sentence, to the 'mass' rather than the 'people' indicates that the crowds he is addressing are precisely oscillating between their a- or pre-political mode of being and their popular identity; a process that can be resolved only by Perón himself. Indeed, moments later the Colonel insists that he is the link that ties the people to the State:

From this hour, which will be historic for the Republic, let Colonel Perón be the bond of union that renders indestructible the brotherhood between the people, the army and the police [la hermandad entre el pueblo, el ejército y la policía]. Let this be an eternal and infinite union, so that this people may grow in the spiritual unity between the authentic and truthful forces of nationality and order.

It is Perón, in short, who ensures that the people will, from now on, coincide with the political - a bond that at once requires and transcends him, generating an 'eternal and infinite' union.

It is crucial at this point to reject one particularly stubborn interpretation of Peronism, according to which Perón was nothing more than an opportunistic autocrat who manipulated the masses for an essentially fascist agenda. ${ }^{7}$ Putting to one side the political implications of this argument (that is, equating Peronism with fascism legitimises US-led Western intervention in Argentina) it also completely erases the part played in the birth of Peronism by the workers' movement (see James 1988). Indeed, as María Roldán, a prominent union leader and a driving force behind the workers' movement that took to the Plaza de Mayo 17 October, recalls in a series of oral history interviews

${ }^{7}$ The claim that Peronism is a brand of fascism that has its roots in Mussolinism is an old one. For an early example, see Blanksten 1953; for a discussion and overview of this debate up until 1980, see Lewis 1980. 
with Daniel James, "the seventeenth arose from our pain" (James 2000, 59). She then goes on to dispel the myth that, as James puts it, "the people just passively received everything" by insisting that "Perón, without the support of the people, wouldn't have been Perón" (ibid., 63). Thus, whilst it was true that "[t]he Argentine people needed a man to follow, and Perón was that man", the relationship between this people and this man was not instigated or indeed directed by the latter: "It's the people who did everything" (ibid.). It is, then, far more accurate to interpret the events that took place on October $17^{\text {th }}$ as a process of mutual co-constitution: although an angry, well-organised mass and a tired, charismatic man entered the Plaza de Mayo that day, a people and a leader left it.

Here, then, we have a clear-cut example of popular identification as Laclau understands it: the people manages fully to constitute itself only through its identification with the leader, whose name and person come to function as an empty signifier that represents the movement as such. In the years that followed, as Perón formalised and rationalised his movement in the guise of the Justicialist Party (named after justicialism, or justicialismo, the name Perón gave to his political programme), this conception of leadership became deeply ingrained in Peronist politics. As he wrote in a 1952 treatise on political leadership, entitled Condúccion Política:

A mass [una masa], generally, has no intrinsic value other than the power of reaction as a mass. Its power, its true power of reaction and action, is in the leaders [los dirigentes] that guide it. A mass gets its worth not from the number of men who form it, but from the quality of the men who lead [coducen] it, because the masses do not think, the masses feel and have more or less intuitive or organised reactions. But who produces them? The one who leads them $[E l$ que las conduce]. (Perón 1952, 200-201)

Populism of the Peronist variant, then, certainly subscribes to the view that any properly populist movement requires a leader.

This is not enough, however: as Laclau argues, popular identification requires an enemy as well as a leader. This aspect is also clearly present in Peronism. Indeed, already in his 17 October speech, Perón is at pains to erect an image of a common enemy who is to be overcome: "Let the unworthy frauds [indignos farsantes] know today that this people do not deceive those who do not betray them." Such bellicose language would soon become a staple of Peronist rhetoric, which tended to set itself up against 'the oligarchy', a term that, at the time, was evocative of the pre-Peronist ruling class (see Romero 2002). Take the following excerpt from a speech given by Eva 'Evita' Perón, Juan's wife, ${ }^{8}$ in 1951:

${ }^{8}$ Unfortunately, I cannot here treat in detail the crucial role played, especially during Perón's first 
It was General Perón who gave [the people] social, moral, and spiritual dignity. [The people] also know that the oligarchy, the mediocre, and the traitors of the Nation are not yet defeated, and that from their filthy lairs, they undermine liberty and the people. But our oligarchy, who always sold itself for a pittance, does not expect the people to stand up this time nor does it realize that the Argentine nation is comprised of honorable men and women who are willing to die to finish off, once and for all, the traitors and the sellouts. (Cited in Dawson 2011, 182)

Thus, Peronism set itself up as the historical opponent of the oligarchy, establishing and mobilising what Laclau calls an antagonistic frontier in order to consolidate its own conception of the popular subject, whose very unity derives from its being 'undermined' by the oligarchs. ${ }^{9}$ Indeed, as Laclau (1977, 188 189) himself wrote in 'Towards a Theory of Populism': "populism in Argentina was to consist precisely in a reunification of the ensemble of interpellations that expressed opposition to the oligarchic power bloc".

In terms of popular identification, then, Peronism instantiates the Laclauian model point by point. All of the constitutive elements that, for Laclau, enter into the making of a people are present: out of unsatisfied social demands arises a social group that succeeds in properly subjectifying itself only when a leader and an enemy present themselves, thus establishing 'the people' as a historical actor. Furthermore, a similar logic is at work in certain more recent varieties of Latin American populism, Chavism being a particularly relevant example. For Chávez, as for Perón, leadership is an integral aspect of any successful populist struggle, forming, as it were, its necessary precondition. "I believe in natural leaders," Chávez notes in a long interview with Marta Harnecker $(2005,54)$, "not in those that are imposed". He adds: "Leaders find themselves in front of an avalanche that drags us forward" (ibid.). Similarly, Chávez mobilises a discourse of enmity, casting his opponents as 'the oligarchy' or 'the corrupt' in a manner highly reminiscent of Perón's rhetoric (see also López Maya \& Panzarelli 2013; Panizza 2013).

When applied to certain Latin American populisms, then, Laclau's theory of populism clearly has significant explanatory potential. But does that make it universally applicable? Or can examples be found of modes of popular identification that trouble the clear waters of Laclauian ontology? Let me now turn to two such examples.

presidential term, by his wife, Eva 'Evita' Perón, who without a doubt formed a crucial element of the Peronist articulation of leadership. Concisely put, Evita was widely seen as the caring, motherly companion to Juan's more militaristic, fatherly style of leadership. For more on Evita's role in Peronism, see for instance María Roldán's testimony in James 2000, 76-84; Dawson 2011, ch. 7; or Romero 2002, 107.

${ }^{9}$ Here again, it should be noted that this dichotomy was not just projected onto the people by the Peronist vanguard; it seems to have been present in the rhetoric of the workers' movement as well. María Roldán, for instance, consistently erects a dichotomous distinction between "the workers of the world" and "oligarchic capital [which] always reemerges to tighten its grip on us" (James 2000, 71). 


\section{Pluralist Populism}

In some ways, the populist agendas of Raphael Correa of Ecuador and Evo Morales of Bolivia resemble that of Chávez: often grouped together as ' $21^{\text {st }}$-century socialism' (see Harnecker 2007) these strands of contemporary left-wing populism stand united in their rejection of global neoliberalism, their heavy reliance on parliamentary elections and referendums, their intimate connection to social movements, and their dedication to the deployment of poverty relief programmes (Ellner 2012). Likewise, and crucially for my present purposes, each of these populisms has used constitutional reform as a key technology of power, implementing new constitutions - approved by referendum - in order to enshrine various human, civil, and social rights, and promote radical democracy (De la Torre \& Arnson 2013, 10). Indeed, under Chávez, a new Venezuelan constitution was drafted in $1999 ;{ }^{10}$ under Correa, a new Ecuadorian constitution was drafted in 2008; and under Morales, a new Bolivian constitution was drafted in 2009. In each case, both the institution of a constitutional assembly and the ratification of the resulting constitution was submitted to a popular vote by referendum.

Aside from establishing the legal and civic boundaries of the State, however, these constitutions also generate something of a decidedly different, and perhaps more fundamental, nature: a certain self-representation of the people. That is, moments of constitutional reform might be seen, following Judith Butler's $(2015,175)$ recent work on the politics of assembly, as entailing "a linguistic form of autogenesis", in which the people (or, indeed, peoples) in whose name the constitution is presented performatively enact their popular identity even as they posit it. In other words, in declaring a constitution, a people constitutes itself as much as its State, its civil society or the grounds of its legal apparatus. Or, in still other, more Laclauian words, a constitution may provide a uniquely effective stage for a process of popular identification.

What, one may now ask, do the Bolivian and Ecuadorian constitutions tell us about the popular identity of the peoples in whose name they have been formulated? The beginning of an answer to this question may be found in their respective preambles (which, as Butler (2015) points out, is where moments of popular self-constitution are most likely to occur). Let me quote selected passages from each at some length, beginning with the Ecuadorian constitution:

We women and men, the sovereign people [el pueblo soberano] of Ecuador RECOGNIZING our age-old roots, wrought by women and men from various peoples [de distintos pueblos],

\footnotetext{
${ }^{10}$ At the time of writing, in February 2019, the Venezuelan constitution is inactive, having been suspended by the Bolivarian government since August 2017.
}

Araucaria. Revista Iberoamericana de Filosofia, Política, Humanidades y Relaciones Internacionales, año $21, \mathrm{n}^{\circ} 42$. Segundo semestre de 2019. Pp. 529-551. ISSN 1575-6823 e-ISSN 2340-2199 doi: 10.12795/araucaria.2019.i42.23 
Celebrating nature, the Pacha Mama (Mother Earth), of which we are a part and which is vital to our existence,

INVOKING the name of God and recognizing our diverse forms of religion and spirituality,

CALLING UPON the wisdom of all the cultures [de todas las culturas] that enrich us as a society,

As HEIRS to social liberation struggles against all forms of domination and colonialism

AND with a profound commitment to the present and to the future,

Hereby decide to build

A new form of public coexistence, in diversity and in harmony with nature, to achieve the good way of living [buen vivir], the sumak kawsay;

A society that respects, in all its dimensions, the dignity of individuals and community groups $[\ldots] .^{11}$

\section{And the Bolivian constitution:}

In ancient times mountains arose, rivers moved, and lakes were formed. Our Amazonia, our swamps, our highlands, and our plains and valleys were covered with greenery and flowers. We populated this sacred Mother Earth with different faces, and since that time we have understood the plurality [la pluralidad] that exists in all things and in our diversity as human beings and cultures. Thus, our peoples [nuestros pueblos] were formed, and we never knew racism until we were subjected to it during the terrible times of colonialism.

We, the Bolivian people, of plural composition [de composición plural], from the depths of history, inspired by the struggles of the past, by the anticolonial indigenous uprising, and in independence, by the popular struggles of liberation, by the indigenous, social and labor marches, by the water and October wars, by the struggles for land and territory, construct a new State in memory of our martyrs.

A State based on respect and equality for all, on principles of sovereignty, dignity, interdependence, solidarity, harmony, and equity in the distribution and redistribution of the social wealth, where the search for a good life [vivir bien] predominates; based on respect for the economic, social, juridical, political and cultural pluralism [pluralidad] of the inhabitants of this land; and on collective coexistence with access to water, work, education, health and housing for all.

We have left the colonial, republican and neo-liberal State in the past. We take on the historic challenge of collectively constructing a Unified Social State of Pluri-National Communitarian law, which includes and articulates the goal of advancing toward a democratic, productive, peace-loving and peaceful Bolivia, committed to the full development and free determination of the peoples [de los pueblos]. [... $]^{12}$

${ }^{11}$ For the original Spanish text of the constitution of Ecuador, see https://web.archive.org/ web/20090320002938/http://www.asambleaconstituyente.gov.ec/documentos/constitucion_de_ bolsillo.pdf; for the English translation, see http://pdba.georgetown.edu/Constitutions/Ecuador/ english08.html.

${ }_{12}$ For the original Spanish text of the constitution of Bolivia, see https://bolivia.infoleyes.com/ 
Let me make a few observations about these excerpts before I turn back to Laclau's theory of populism.

The first thing to note is that whilst both preambles speak in the first person plural, the "we" they speak of is not itself a straightforwardly singular people: both constitutions speak in the name of peoples (or pueblos). The Bolivian constitution further elaborates on this point, asserting that "the Bolivian people" is "of plural composition". We have in both cases, then, a people that is not one; a "sovereign people" made up of multiple peoples. This multiplicity, or plurality, is reflective of the high number of diverse indigenous communities and identities that exist in both countries, many of which have their own languages, practices, and political cultures. Accordingly, both constitutions recognise a wide variety of languages, including all indigenous languages, and protect forms of communal democracy that exist amongst indigenous communities.

A second remarkable feature of these preambles is that both emphasise Latin America's colonial history as well as the anti-colonial struggles that shaped Ecuador and Bolivia as we now know them. Here, the possibility of popular identification in spite of far-reaching internal differences is rooted in a shared heritage of oppression and struggle; one that ranges from "the depths of history" to "the neo-liberal State", as the Bolivian constitution puts it. In both constitutions, the theme of anti-colonialism is reflected in their respective sections on international relations. Thus article 416.8 of the Ecuadorian constitution states that Ecuador "condemns all forms of imperialism, colonialism, and neocolonialism and recognizes the right of peoples to resist and free themselves from all forms of oppression". Similarly, article 255.II.2 of the Bolivian constitution asserts the following guiding principle of Bolivia's attitude to international relations: "Rejection and condemnation of all forms of dictatorship, colonialism, neocolonialism and imperialism".

A third notable characteristic that these preambles have in common is that they both make reference to "a good way of living", or buen vivir in the Ecuadorian constitution and vivir bien in the Bolivian. This notion, which draws upon a wide range of indigenous traditions and practices, points towards an alternative way of living, one in which humans live in harmony with nature and with one another (see also Mignolo 2011, ch. 7). Woven throughout both texts, the notion of living well was originally incorporated into these constitutions, as Eduardo Gudynas has demonstrated, as "a reaction to the neo-liberal market reforms in the late 1990s and early 2000s" $(2011,442)$. However, it also has a broader set of connotations, signifying a generalised decolonial critique of "Western Modernity", thus "open[ing] the doors to different sets of understandings, rationalities and feelings of the world" (ibid., 444-445).

norma/469/constituci\%C3\%B3n-pol\%C3\%ADtica-del-estado-cpe. For the English translation, see https://www.constituteproject.org/constitution/Bolivia_2009.pdf.

Araucaria. Revista Iberoamericana de Filosofia, Politica, Humanidades y Relaciones Internacionales, año $21, \mathrm{n}^{\circ} 42$. Segundo semestre de 2019. Pp. 529-551. ISSN 1575-6823 e-ISSN 2340-2199 doi: 10.12795/araucaria.2019.i42.23 
Viewed in this way, the invocation of living well may be seen as an extension of the second feature that marks these constitutions: insofar as they establish as their cornerstone the rejection of their peoples' history of colonisation, both constitutions actively develop an alternative, anti- or decolonial conception of social, economic, and indeed personal life that may operate as a counterpoint to colonialism's contemporary (i.e. neoliberal) guise.

Let me gather together the various threads I have set out here. If one views the preambles of these two constitutional texts as moments of popular identification, what emerges is an intriguing picture. Here, "the people" considers itself of plural composition, at once "sovereign" but also essentially heterogeneous and internally diverse. This people, which is made up of multiple peoples, is united through its common heritage, which consists first of all of a shared struggle against colonialism, racism and domination. As a counterpoint to its colonial past, this people holds up the principle and practice of living well (or vivir bien or buen vivir) as the cornerstone of its life in common, projecting an alternative horizon to the one set out by European modernity. How does this image of popular identification compare to Laclau's theoretical framework? What, in other words, remains of the theory of populism set out in On Populist Reason when it is confronted with the populisms that have generated these preambles and their concomitant peoples? ${ }^{13}$

My contention is that insofar as these texts represent a distinct form of popular identification, they trouble some of the core assumptions of Laclau's theory of populism. First, whilst for Laclau identification works through differentiation, which necessarily leads to the exclusion of a radical Other, in these preambles popular identity is premised upon the inclusion of difference. This is, indeed, precisely what the Bolivian constitution seems to communicate when it asserts that the Bolivian "peoples" understand "the plurality that exists in all things and in our diversity as human beings and cultures". Here, no enemy or antagonistic frontier is needed to complete the process of popular identification, as the identity that is being constructed has no need, indeed no desire, to attain a state of singularity: it insists on its own constitutive plurality and diversity; it insists on being a people that is not one. Thus, in the acknowledgement of their multiplicity, these peoples, these pueblos, seem to

${ }^{13}$ I am aware that in setting up the problem in this way I have already departed from Laclau's approach to popular identification. Indeed, the latter would primarily look for moments of popular self-construction in political campaigns, deploying what is often termed 'discourse analysis' (see Howarth 2000) to interpret rhetorical strategies and thus to isolate key moments of identity-formation. Following a more strictly Laclauian method, one may well find that the populisms of Correa and Morales in fact comply very well with the model developed by Laclau, including its emphasis on leadership (see for instance Panizza 2013). Yet, I would insist that there is no principled reason to exclude constitutional documents from the realm of discourse, or to insist that popular identification takes place only within the bounds of the rhetorical. Indeed, to deny the centrality of constitutional reform to the variants of populism also known as ' $21^{\text {st }}$ century socialism' would be precisely to derecognise the radical potential in such a strategy.

Araucaria. Revista Iberoamericana de Filosofia, Política, Humanidades y Relaciones Internacionales, año $21, \mathrm{n}^{\circ} 42$. Segundo semestre de 2019. Pp. 529-551. ISSN 1575-6823 e-ISSN 2340-2199 doi: 10.12795/araucaria.2019.i42.23 
require no constitutive Other whose radical difference establishes their own cohesion.

What, one may then ask, does provide these peoples with their unity-indiversity? What ensures their sameness, if not an excluded enemy? The answer to this question seems to be their shared history of anti-colonial struggle: they are united "as heirs to social liberation struggles against all forms of domination and colonialism", as the Ecuadorian constitution has it. This marks the second way in which these preambles trouble Laclau's theoretical model: whilst for the latter, the play of differences within which any identity constitutes itself is horizontal, taking place within a bounded system of meaning and signification that maps onto the field of the social, the anti-colonialism that here functions as the cornerstone of popular identification is historical in nature. These identities come "from the depths of history", as the Bolivian constitution has it, inspired and held together by a heritage of struggles against racism and oppression. Their meaning thus does not derive from the power relations and discursive formations that structure the social in the present; it derives from shared modes of resistance to the power relations and discursive formations that structured the past and that continue to exert power in the present, both because the legacies of colonialism have not yet been overcome (hence the rejection, in both constitutions, of "all forms of neocolonialism") and because the memory of past colonial oppression lives on.

Third, the Laclauian theorem that, in the final analysis, a populist movement requires a leader seems void here. Indeed, for Laclau, the name of the leader is the only type of empty signifier that can stand for 'the people' as a whole because of its ontological singularity. It is, in other words, what binds the multiplicity of social demands without rendering it void. However, singularity is the very antipode to the form of popular identification unfolding in these constitutions, which hinges on plurality, as already discussed, as well as on harmony. Expressed as buen vivir or vivir bien, the principle of living in harmony (with nature as well as with one another) defies the need for the principle of singularity as the final coagulant of group identity. The principle of living well, then, provides an answer to the question, how can a plural identity (as peoples, or pueblos) be maintained as a quasi-singularity (a sovereign people, or pueblo soberano)? This is not to say that leadership plays no role in populist politics of this sort; it is to say, rather, that a popular identity built upon plurality rather than unity does not have to pass through the moment of leadership to establish itself.

To summarise, the form of popular identification performed in the preambles of the constitutions of Ecuador and Bolivia defies the logic that, in Laclau's account, populist identity-formation follows. Or, more forcefully put, this form turns the Laclauian model on its head: rather than requiring exclusion, 
it presupposes inclusion; rather than depending upon a horizontal play of differences in the present, it draws its inspiration from forms of collective struggle in the past; and rather than necessitating leadership to unify disparate social demands, it counsels harmony as a means of embracing plurality. It is perhaps not surprising that this form of populism would reject a conceptual constellation according to which self-identification involves exclusion, differentiation and vilification through othering, since this constellation is the hallmark of the racist, colonial enterprise that these peoples precisely seek to break and break free from.

\section{Concluding Remarks}

Faced with the collapse of neoliberal governmentality into crypto- and notso-crypto-fascisms all over the world, and the concomitant rise in demagoguery, racism and nationalism, ${ }^{14}$ the Left once more finds itself asking the perennial question, what is to be done? For those who have adopted the Laclauian model, the answer is straightforward: the crisis of neoliberalism marks the possibility for a left-wing populism to emerge and mount a struggle for hegemony. In this account, neoliberal strategy — which, at least in the 1970s and 80s, was populist through and through - must be turned against itself by being articulated to a left-wing rather than a right-wing agenda (for this argument, see Mouffe 2018). For these authors, in other words, the pendulum may be made to swing back.

The decolonial, pluralist form of populism that I have sought to unpack in this article seems to point in a different direction. Here, neoliberalism is not seen as an ambivalent political formation from which the Left may learn valuable lessons in populist strategy; rather, the neoliberal State comes to appear as the latest chapter in the history of colonialism and neocolonialism, a form of governmentality driven by racial differentiation and colonial modes of exploitation. The problem faced by this form of populism is, then, a radically different one: rather than marking a strategic quandary, here the challenge of populism is how to overturn a formation of power that has its roots in centuriesold colonial practices and discourses. The objective is therefore not to make

${ }^{14}$ For an incisive account of this process, see Brown 2018. To suggest that neoliberalism has collapsed into fascism, racism and demagoguery is not to argue that neoliberalism never was fascistic or racist or that it did not rely upon the wiles of demagogues, nor is it to imply that with this collapse, the playing field has once again been levelled, rendering everyone equally prone to state repression or racism. Indeed, neoliberalism has always functioned by way of racialised logics, both in terms of its differential application to differently racialised subjects (see Dawson \& Francis 2015; Issar 2019; Kapoor 2013) and in terms of its differential roll-out across the globe, where populations racialised as Other were conceptualised as requiring authoritarian control, a process epitomised by the neoliberal defence of and participation in the 1973 coup in Chile (see Cornelissen 2017). The point, then, is that this 'collapse' marks not a displacement of a neoliberal paradigm by a racist or fascist one but the explication and intensification of its internal logic. 
the pendulum swing back; the objective is to dismantle the pendulum, as it were. Since the question of decoloniality is far too large to be able to receive adequate treatment here, I wish to conclude by briefly discussing two specific implications of my argument, one philosophical and one political, for debates on populism in particular and critical political thought more generally.

Philosophically, the pluralist case poses a challenge to the ontological framework developed by Laclau, troubling the category of identity and its relation to other concepts such as antagonism, difference and exclusion. When approached through a decolonial lens, this conceptual constellation comes to appear not as a neutral philosophical device, but as a real historical force that, in the Latin American context, underpinned racism and domination. This should prompt a careful reconsideration of the concept of identity, taking especially decolonial understandings of exclusion into account. Perhaps we must reconsider the by now commonplace argument that "there is no way of circumnavigating the fact that, both historically and conceptually speaking, th[e] category [of the people] is constituted on the basis of a necessary exclusion" (Bosteels 2016, 2). A way out of this fatalistic truism may, perhaps, be found in the notion of plurality-if, that is, it is read not in its liberal guise, where it indicates the bland (if somewhat conceited) toleration of all supposedly reasonable viewpoints, but in its decolonial one, where it refers to an inclusive vision of life in common.

Politically, the pluralist paradigm unsettles the assumption, defended with particular vehemence by Mouffe, that populist politics necessarily involves a certain mode of charismatic leadership. Once this has been conceded, it becomes all too easy to reject any critique of the notion of leadership as politically naïve and strategically fruitless, as a result of which critique makes way for the effort to distinguish the 'good' leaders from the 'bad' ones on the basis of an essentially arbitrary measure. ${ }^{15}$ Yet if, as the pluralist model holds out, popular self-formation is possible on the basis of a shared heritage of struggle against domination, the notion of leadership becomes not only unnecessary but

15 The discussion of leadership presented in For a Left Populism provides a striking example of this logic. To quote Mouffe at length: "The role of the leader in the populist strategy has always been a subject of criticism and it is the reason why those movements are often accused of being authoritarian. Many people find charismatic leadership very dangerous and no doubt it can have negative effects. But independently of the fact that it is very difficult to find examples of important political movements without prominent leaders, there is no reason to equate strong leadership with authoritarianism. Everything depends on the kind of relation that is established between the leader and the people. In the case of right-wing populism, it is a very authoritarian relation where everything comes from the top without real grassroots participation" (Mouffe 2018, 70). Not only does Mouffe here pre-emptively declaw any critique of leadership as a concept, she also proposes a measure to distinguish leadership from authoritarianism that seems empirically and historically incorrect. Indeed, right-wing populisms and/or authoritarianisms that have a very strong grassroots presence abound: one need only think of the type of internet-based mobilisation that the Trump campaign relied upon, or the widespread popular support a leader like Erdoğan enjoys.

Araucaria. Revista Iberoamericana de Filosofia, Política, Humanidades y Relaciones Internacionales, año $21, \mathrm{n}^{\circ} 42$. Segundo semestre de 2019. Pp. 529-551. ISSN 1575-6823 e-ISSN 2340-2199 doi: 10.12795/araucaria.2019.i42.23 
potentially problematic, summoning the spectre of (racialised) subordination. The pluralist model, then, potentially relegitimises radical critiques of the very category of leadership even as it creates space for a critical and more systematic appraisal of existing forms of radical populism and their leadership practices.

Populism, as a concept and as a practice, has certainly not yet drawn its last breath. Yet it would seem that if it is to learn from and about the populist phenomenon, critical political theory has much to gain from studying the decolonial discourses that inform certain of its contemporary variations. Perhaps the first conclusion that such a study might reach is that no amount of ontology - and especially if that ontology is of European descent - can determine once and for all by which means any people, or indeed peoples, see fit to articulate themselves. 


\section{References:}

Biglieri 2015: P. Biglieri, "Laclau: The Philosopher and Political Activist," Critical Studies, 1: 40-43.

Blanksten 1953: G. Blanksten, Perón’s Argentina (Chicago, 1953).

Bosteels 2016: B. Bosteels, "Introduction: This People Which Is Not One," in A. Badiou, P. Bourdieu, J. Butler, G. Didi-Huberman, S. Khiari \& J. Rancière, What is a People? (New York, 2013).

Brown 2018: W. Brown, "Neoliberalism's Frankenstein: Authoritarian Freedom

in Twenty-First Century 'Democracies'," Critical Times 1(1): 60-79.

Butler 2015: J. Butler, Notes Toward a Performative Theory of Assembly (Cambridge, MA, 2015).

Canovan 1981: M. Canovan, Populism (New York, 1981).

Cornelissen 2017: L. Cornelissen, "It is Anti-Colonialism Which is the Problem': Colonialism, Development, and Cold-War Neoliberalism," conference paper presented at University of Brighton, September 2017.

Critchley \& Marchart 2004: S. Critchley \& O. Marchart, Laclau: A Critical Reader (London, 2004).

Dawson 2011: A. Dawson, Latin America since Independence: A History with Primary Sources, (New York, 2011).

Dawson \& Francis 2015: M.C. Dawson \& M.M. Francis, "Black Politics and the Neoliberal Racial Order," Public Culture, 28(1): 23-62.

Devenney 2004: M. Devenney, Ethics and Politics in Contemporary Theory: Between Critical Theory and Post-Marxism (London, 2004).

Ellner 2012: S. Ellner, "The Distinguishing Features of Latin America's New Left in Power: The Chávez, Morales, and Correa Governments," Latin American Perspectives, 39(1): 96-114.

García Agustín \& Briziarelli 2018: Ó. García Agustín \& M. Briziarelli, Podemos and the New Political Cycle: Left-Wing Populism and Anti-Establishment Politics (Cham, 2018).

Gauna 2017: A.F. Gauna, "Explaing Populism Beyond Laclau: A HistoricalComparative Assessment of On Populist Reason," Thesis Eleven 140(1): $38-55$.

Gudynas 2011: E. Gudynas, “Buen Vivir: Today's Tomorrow,” Development 54(4): 441-447.

Harnecker 2005: M. Harnecker, Understanding the Venezuelan Revolution: Hugo Chávez Talks to Marta Harnecker (New York, 2005).

Harnecker 2007: M. Harnecker, Rebuilding the Left (London, 2007).

Howarth 2000: D. Howart, Discourse (Buckingham, 2000).

Howarth 2015: D. Howarth, Ernesto Laclau: Post-Marxism, Populism and Critique (London, 2015). 
Issar 2019: S. Issar, “Theorising 'Racialised Primitive Accumulation': Settler Colonialism, Slavery and Racial Capitalism," conference paper presented at University of Brighton, January 2019.

James 1988: D. James, “October 17th and 18th, 1945: Mass Protest, Peronism and the Argentine Working Class," Journal of Social History, 21(3): 441461.

James 2000: D. James, Doña María’s Story: Life History, Memory, and Political Identity (Durham, 2000).

Kapoor 2013: N. Kapoor, "The Advancement of Racial Neoliberalism in Britain," Ethnic and Racial Studies, 36(6): 1028-1046.

Katsambekis 2017: G. Katsambekis, "The Populist Surge in Post-Democratic Times: Theoretical and Political Challenges," The Political Quarterly, 88(2): 202-210.

Laclau 1996: E. Laclau, Emancipation(s) (London, 1996).

Laclau 2005a: E. Laclau, On Populist Reason (London, 2005).

Laclau 2005b: E. Laclau, "Populism: What's in a Name?," in F. Panizza, ed.: Populism and the Mirror of Democracy (London, 2005).

Lewis 1980: P.H. Lewis, "Was Perón a Fascist? An Inquiry into the Nature of Fascism," Journal of Politics, 42(1): 242-256.

López Maya \& Panzarelli 2013: M. López Maya \& A. Panzarelli, "Populism, Rentierism, and Socialism in the Twenty-First Century: The Case of Venezuela," in C. de la Torre \& C.J. Arnson, eds.: Latin American Populism in the Twenty-First Century (Baltimore, 2013).

Marchart 2007: O. Marchart, Post-Foundational Political Thought: Political Difference in Nancy, Lefort, Badiou and Laclau (Edinburgh, 2007).

Mignolo 2011: W. Mignolo, The Darker Side of Western Modernity: Global Futures, Decolonial Options (Durham, 2011).

Mouffe \& Errejón 2016: C. Mouffe \& Í. Errejón, Podemos: In the Name of the People (London, 2016).

Mouffe 2005: C. Mouffe, “The 'End of Politics' and the Challenge of Rightwing Populism," in F. Panizza, ed.: Populism and the Mirror of Democracy (London, 2005).

Mouffe 2018: C. Mouffe. For a Left Populism (London, 2018).

Panniza 2005: F. Panizza, "Introduction: Populism and the Mirror of Democracy," in: F. Panizza, ed.: Populism and the Mirror of Democracy (London, 2005).

Panizza 2013: F. Panizza, "What Do We Mean When We Talk About Populism?," in C. de la Torre \& C.J. Arnson, eds.: Latin American Populism in the Twenty-First Century (Baltimore, 2013).

Page 1983: J. Page, Perón: A Biography (New York, 1983).

Perón 1952: J.D. Perón, Conducción Política (Buenos Aires, 1952). 
Romero 2002: L.A. Romero, A History of Argentina in the Twentieth Century (University Park, 1994).

Schamis 2013: H.E. Schamis, "From the Peróns to the Kirchners: "Populism" in Argentine Politics," in C. de la Torre \& C.J. Arnson, eds.: Latin American Populism in the Twenty-First Century (Baltimore, 2013).

Stavrakakis et al. 2017: Y. Stavrakakis, G. Katsambekis, N. Nikisianis, A. Kioupkiolis \& T. Siomos, "Extreme Right-Wing Populism in Europe: Revisiting a Reified Association," Critical Discourse Studies, 14(4): 420439.

Taggart 2000: P. Taggart, Populism (Buckingham, 2000).

De la Torre \& Arnson 2013: C. de la Torre \& C.J. Arnson, "Introduction: The Evolution of Latin American Populism and the Debates Over Its Meaning," in C. de la Torre \& C.J. Arnson, eds.: Latin American Populism in the Twenty-First Century (Baltimore, 2013).

Villacañas Berlanga 2010: J.L. Villacañas Berlanga, "The Liberal Roots of Populism: A Critique of Laclau," transl. J. Ledo, CR: The New Centennial Review, 10(2): 151-182.

Žižek 2006: S. Žižek, “Against the Populist Temptation,” Critical Inquiry 32(3): 551-574. 
